
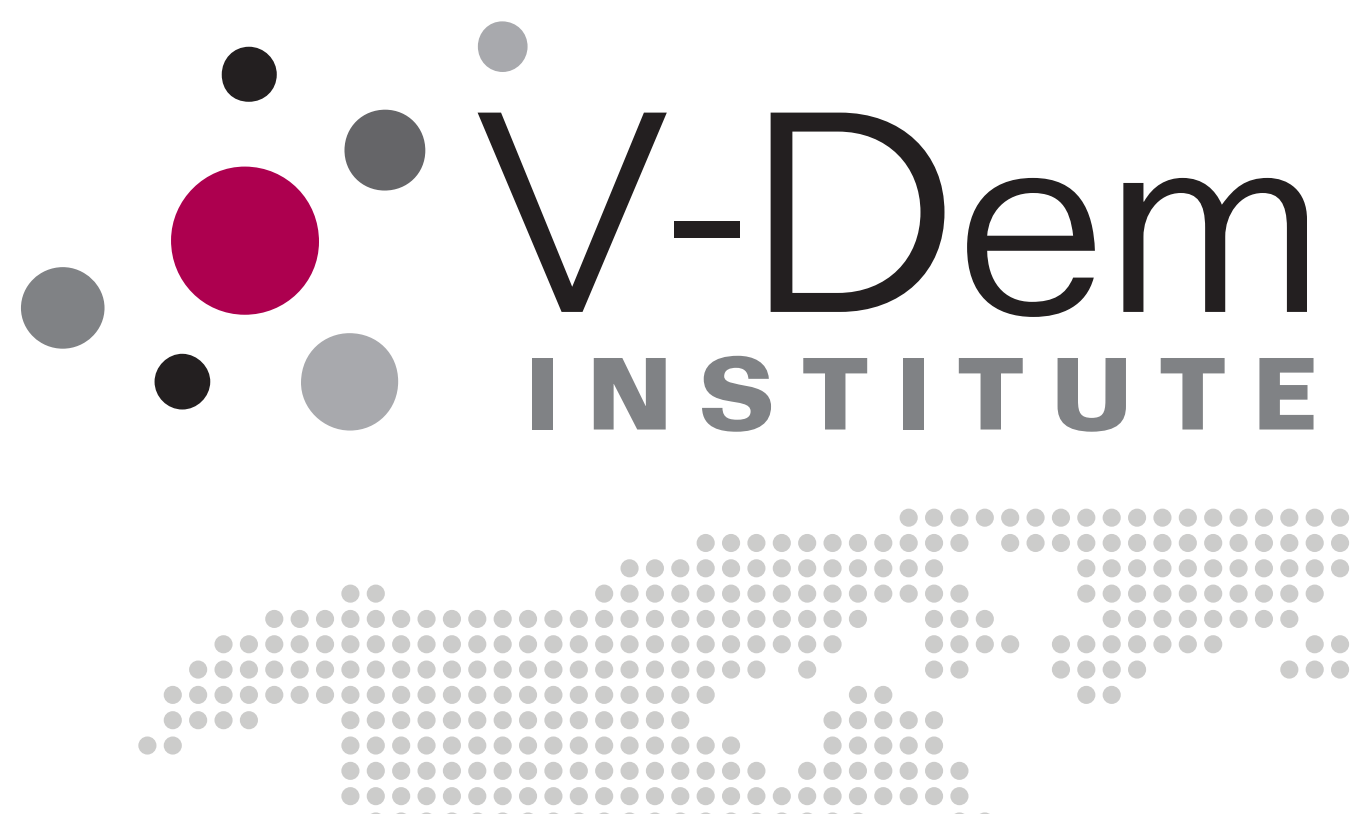
100900
100

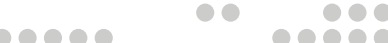

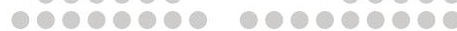
$0000000900009000 \mathrm{c}$ $0000000000000000000 \mathrm{C}$

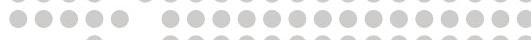
10.

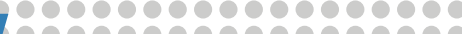

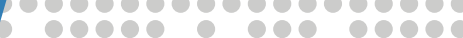

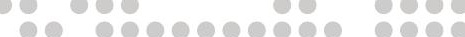

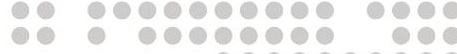

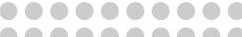
How to Build Democracy after Authoritarian Breakdown: Insights

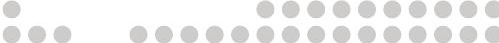

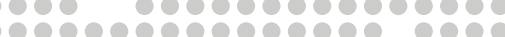

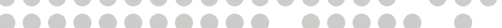

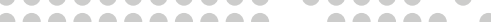
from a Mixed Methods Approach

from a Mixed Methods Approach

Jean Lachapelle, Sebastian Hellmeier, Anna Lührmann
000000000

0000000

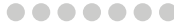

100000

$\circ \circ 000$

1000

000

10

100

89

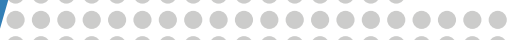
10000000000000000000 20000000000000000000

-

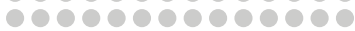

ó

0000000000

00000000000

000000000

-

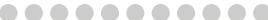

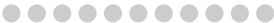

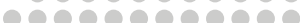

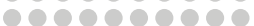

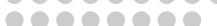

00000000

100000

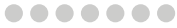

000000

000

100

政

\author{
(n)
}

(1)

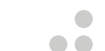

10 
Varieties of Democracy (V-Dem) is a new approach to conceptualization and measurement of democracy. The headquarters - the V-Dem Institute - is based at the University of Gothenburg with 23 staff. The project includes a worldwide team with 5 Principal Investigators, 19 Project Managers, 33 Regional Managers, 134 Country Coordinators, Research Assistants, and 3,500 Country Experts. The V-Dem project is one of the largest ever social science research-oriented data collection programs.

Please address comments and/or queries for information to:

\author{
V-Dem Institute \\ Department of Political Science \\ University of Gothenburg \\ Sprängkullsgatan 19, Box 711 \\ 40530 Gothenburg \\ Sweden \\ E-mail: contact@,v-dem.net
}

V-Dem Working Papers are available in electronic format at www.v-dem.net.

Copyright (C2021 by authors. All rights reserved. 


\title{
How to Build Democracy after Authoritarian Breakdown: Insights from a Mixed Methods Approach*
}

\author{
Jean Lachapelle \\ Postdoctoral Research Fellow \\ $V$-Dem Institute, University of Gothenburg \\ Sebastian Hellmeier \\ Postdoctoral Research Fellow \\ $V$-Dem Institute, University of Gothenburg \\ WZB Berlin Social Science Center \\ Anna Lührmann \\ Assistant Professor \\ $V$-Dem Institute, University of Gothenburg
}

\footnotetext{
* Please direct correspondence to Jean Lachapelle (jean.lachapelle@v-dem.net). We thank Lukas Bernhard, Julian Voss and Shreeya Pillai for their skillful research assistance and participants in seminars at the University of Gothenburg (2/2020) and University of Khartoum (2/2020) for their input. This research was supported by Vetenskapsrådet [grant number 2018-016114], PI: Anna Lührmann and European Research Council, Grant 724191, PI: Staffan I. Lindberg, V-Dem Institute, University of Gothenburg, Sweden as well as by internal grants from the Vice-Chancellors office, the Dean of the College of Social Sciences, and the Department of Political Science at University of Gothenburg.
} 


\begin{abstract}
Mass movements that are able to overthrow a dictator do not always lead to democracy. Transition periods present narrow windows of opportunity in which activists face difficult decisions to build democracy and prevent authoritarian relapse. Existing scholarship offers limited guidance for prodemocracy forces because it focuses on unchangeable structural factors and cases with a known outcome. We propose an innovative approach for finding informative comparisons for ongoing transitions after authoritarian breakdowns. We quantify the similarity between all breakdowns caused by mass uprisings since 1945 based on their structural preconditions. We then apply our approach to Sudan's ongoing transition and draw lessons from three similar cases: Benin in 1990, the Philippines in 1986 (successful democratization) and Burma in 1988 (failed democratization). Our case studies suggest that democratic transition is possible in Sudan if pro-democracy forces maintain unity, build inclusive political agendas and keep the military committed to the democratic process.
\end{abstract}

Keywords: Democratization, democratic transition, authoritarian breakdown, matching, mixed methods 


\section{Introduction}

Mass uprisings against autocratic rule are rare and unexpected events that raise hopes of democratization. Yet overthrowing a dictator is only the first step. Daunting tasks still lie ahead for pro-democratic forces after they have ousted a dictator, as most mass uprisings against authoritarian rule do not result in democracy. According to Geddes, Wright and Frantz (2014), only $41 \%$ of mass uprisings that ousted dictatorships after the Second World War were followed by democratization. Pro-democratic forces face a myriad of challenging decisions after an autocrat's ouster, for instance, about whether to engage in formal politics, prosecute or compromise with old regime elites, or whether to unite behind one pro-democratic leader or encouraging political pluralism.

What can political actors do in the wake of authoritarian regime breakdown to facilitate democratic transition? How can they learn from other historical cases? This study employs an innovative approach to address these questions. Building on advances in matching methods (Nielsen 2016), we propose a framework for selecting comparative cases in studies of democratic transitions. We identify 22 structural factors, including democratic history, military size and level of development, that extant political science scholarship relates to a country's chances of democratization and that are exogenous to the decisions of political actors during the transition period. Keeping these factors constant allows us to find cases of successful and failed transitions in which actors' decisions most likely made a difference and that hold lessons for pro-democracy forces operating under similar structural conditions.

As a proof of concept, we present a comparative case study of the ongoing transition in Sudan, with historical cases of successful and failed democratic transitions selected through our matching analysis. The method points to cases beyond Africa and the Middle East that experts may not necessarily consider when thinking about comparative cases and yet can shed light on the uprising that ousted Sudanese dictator Omar al-Bashir in 2019. These cases are Benin in 1990, the Philippines in 1986, and Burma/Myanmar in 1988. Whereas Benin and the Philippines successfully transitioned to democracy after their dictator was toppled, Burma/Myanmar did not. We suggest that this heterogeneity in outcomes despite similar structural conditions points to an important role for actors' decisions in determining whether a country democratizes or not. Our case studies suggest that democratic transition might be possible in Sudan if pro-democracy forces maintain unity, build inclusive political agendas, keep factions in the military committed to the democratic process and secure international support. 
Our approach makes several contributions to existing research on democratic transitions. First, instead of comparing countries that are geographically or culturally proximate, we use a theoretically motivated list of structural factors that previous research has deemed important for transitions. This allows us to find comparative cases that may not be obvious at first sight and can be highly informative. Second, existing scholarship focuses largely on structural factors like economic development or natural resources that activists cannot change. Building on this scholarship, we show that after controlling for these factors, there is still substantial variation in democratization outcomes, which we attribute to the actors' agency. Finally, we depart from existing scholarship by comparing a transition with a yet unknown outcome to completed cases. We argue that these theoretically-founded comparisons are especially valuable for transitions that are still ongoing because this is the phase where comparative evidence is most needed.

\section{Learning from "most similar" transitions}

Political scientists often compare different countries, regions, or organizations in order to explain political phenomena. A large literature is devoted to designing methods for the optimal selection of cases for improving inference (King, Keohane and Verba, 1994; Brady and Collier, 2004). In both quantitative and qualitative research traditions, the goal is often to select cases that are most similar on some set of structural characteristics and only differ on one independent variable of interest (Iacus et al., 2012; Ho et al., 2007). Such “most similar" case selection, in reference to John Mill's work also called Method of Difference, is challenging in practice because a very large number of factors could theoretically be relevant, and it is unclear which ones to choose ("many variables, small number of cases" [Lijphart, 1971: 685]).

Given these difficulties, scholars often select cases that are geographically proximate and share a common culture, history or civilization to account for multiple and potentially unobserved structural differences that could confound the results (Anckar, 2008). Although valid (see e.g., de Meur and Berg-Schlosser, 1996; Morency-Laflamme, 2018), this approach limits what lessons can be learned when we are interested in one case in particular - such as Sudan 2019 - as the number of comparable cases from neighboring countries might be very small. This is an issue, in particular when studying rare events such as authoritarian regimes breakdowns or mass uprisings. In addition, factors other than geographical proximity and cultural similarity can be important structural confounders. Thus, in many studies, cases from other world regions could be more suitable for systematic comparison. As a recent study by Bogaards (2019) reveals, many case studies in democratization research only apply systematic rules to case selection implicitly, if at all, which limits our ability to draw valid conclusions from country comparisons. 
Moreover, existing scholarship emphasizes structure over agency. A large scholarship assesses the effects of a country's background characteristics - including the level of economic development (Boix, 2003), reliance on oil resources (Ross 2001), and civil society strength (Brownlee, Masoud, and Reynolds, 2015) - on democratization. In contrast, agent-oriented approaches focus on elite actors and the decisions that they take (Di Palma, 1990), including whether to demobilize (Ketchley, 2017), hold early or late elections (Brancati and Snyder, 2013), and whether to prosecute former regime elites (Quinn, 2009). While the latter is gaining some traction (Pinckney, 2020), structuralist explanations are still more common but less useful for those who want to push for democratization because they cannot alter structural conditions in the short run.

Finally, scholarly research mainly focuses on completed, past transitions offering little guidance for pro-democracy activists when they need it most, namely while a transition is ongoing. While this approach is perfectly in line with the scientific method, it neglects that important lessons from other cases can be drawn without knowing the outcome of the main case of interest.

We propose an approach for finding useful comparisons for ongoing transitions after authoritarian breakdowns focusing on what actors can do to increase the chances of a successful transition. As a first step, we compile data on various structural background factors that affect whether or not a country is more or less likely to democratize for all cases of authoritarian breakdowns caused by mass uprisings since 1945. Second, we quantify the similarity between them using the Mahalanobis distance (Ho et al., 2007; Imai and Ratkovic, 2014), a widely used metric for measuring similarity between observations in quantitative and qualitative research (Nielsen 2016). The method allows us to identify most similar cases among the universe of cases. Third, we apply our methods to Sudan as a case of an ongoing transition and conduct a small-n case comparison with cases with similar structural preconditions. We draw lessons from actors' choices in Benin and the Philippines (successful democratization) and Burma/Myanmar (failed democratization) to identify takeaways for pro-democracy forces in Sudan.

\section{Identifying and quantifying structural conditions}

Our universe of cases consists of all authoritarian regime breakdowns prompted by mass uprisings since 1945. The list of regime breakdowns caused by mass uprisings is based on the Authoritarian Regimes Dataset by Geddes, Wright and Frantz (GWF, 2014), which covers the period 1945-2010. 
For the post-2010 years, we added six cases of breakdowns based on a review of the relevant literature, which leaves us with 44 cases in total since $1945 .{ }^{1}$

We treat those cases as successful that had become and remained democratic within five years after the breakdown. ${ }^{2}$ By these standards, 24 countries had successfully transitioned to democracy and 18 had failed - including Sudan in 1985. In two cases, Algeria (2019) and Sudan (2019), the outcome of the transition is still unknown.

Our objective is to derive a measure of similarity between cases of regime breakdown. To do so, we conducted a review of existing scholarship on democratic transitions and compiled a list of 22 structural variables believed to influence democratization. ${ }^{3}$ Our selected variables cover seven major areas: economic development, civil society, regime type, democratic legacies, instability, inequality, demographics, and regional factors. A full list of variables can be found in Table 1.

First, we include variables that capture countries' different levels of economic development. Economic factors matter for democratization in multiple ways (Haggard \& Kaufman, 2018). According to modernization theory (Inglehart \& Welzel, 2009), economic development helps to build up and empower pro-democracy forces by increasing citizens' economic and social resources. Economic crises are, in some cases, a direct cause of autocratic breakdown and weigh heavily on the transition process (Przeworski, 1995). In addition, economic development is associated with capital mobility, which is why elites in well-developed regimes might be more open to democracy as they can evade taxes (Boix, 2003). In the matching analysis, we, therefore, include total GDP per capita, GDP growth per capita (Feenstra, Inklaar, \& Timmer, 2015) and infant mortality as an indicator for development (Coppedge et al. 2020, based on gapminder.org). Existing research also emphasizes the importance of natural resources for authoritarian persistence and democratization, which is why we add data on oil and gas production per capita (Ross \& Mahdavi, 2015; Ross, 2001).

Second, we include a measure of civil society strength. A strong civil society is a crucial prerequisite for successful democratization (Bernhard \& Karakoc, 2007). The degree of organization of civil society affects the dynamics of mass-based mobilization and has an impact on whether or not opposition forces can organize and negotiate about the transition outcome with former regime elites and the military. Civil society strength also matters for stabilizing democracy once it has been established as it increases accountability of the state (White, 1994). Some authoritarian regimes do

\footnotetext{
${ }^{1}$ Egypt (2011), Tunisia (2011), Libya (2011), Yemen (2012), Algeria (2019), and Sudan (2019).

2 For the cases until 2010, we used GWF's coding of democracy. For the other six, we based this assessment on V-

Dem's Regimes of the World measure (Lührmann, Tannenberg and Lindberg 2018).

${ }^{3}$ For an overview of relevant factors, see Geddes (2013).
} 
not permit any kind of civil society activity, while others allow limited engagement. V-Dem's core civil society index provides an aggregated measurement of government control over, and repression of civil society (Coppedge et al., 2020: 275) and thus takes these important differences between regimes prior to regime breakdown into account.

Third, we consider differences in regime type of the outgoing regime and potential legacies as they profoundly shape a country's pathway to democracy. For instance, prospects for democratization look different after the breakdown of military or single-party regimes. Militaries with a history of being in power are determined to maintain their prerogatives at the end of the transition (Brownlee et al., 2015), and they are likely to intervene in short democratic experiments (Bratton \& Van de Walle, 1997). More generally, a loyal military is crucial to keep dictators in power during "endgame scenarios" (Croissant et al., 2018). Therefore, we include recently developed measures of the executive's power base. Teorell and Lindberg (2019) provide a continuous measurement of the importance of the military, a dominant party and hereditary rule. Emphasizing the crucial role of the military as the ultimate arbiter of major political decisions, we add information on the military personnel per capita and military spending per capita from the Correlates of War project (Singer, Bremer, \& Stuckey, 1972). Moreover, we add an indicator for the protection of human rights under the old regime (Fariss, 2014), the level of electoral democracy (from V-Dem), and the democratic experience a country has accumulated up to the point of regime breakdown. This helps us to identify cases with similar democratic legacies, similar ruling structures, and levels of state repression.

Fourth, a country's history of (in)stability affects prospects for future stability. Coup d'états are a prime challenge for democracy and past coups are, together with other factors, a good predictor for future coups (Belkin \& Schofer, 2003). For that reason, our matching approach uses information on the length of tenure of the previous authoritarian leader and the number of previous coup attempts. Countries with a long history of attempts to remove the leader are likely different from countries with very few coup attempts. These data are taken from the Rulers, Elections, and Irregular Governance (REIGN) dataset data set (Bell, 2016). Similarly, we include information on the level of intra-state conflict during the last five years before regime breakdown using data from the Uppsala Conflict Data Program (Sundberg \& Melander, 2013). Intra-state conflicts such as civil war or territorial conflicts make it more challenging to achieve consensus on the future path of the country and produce grievances that can cast a shadow on the transition process. 
Fifth, we include two V-Dem measures of inequality: Power distribution by urban-rural location and group equality with respect for civil liberties. Inequality is said to facilitate civil conflict as excluded groups have strong incentives to challenge the status quo and demand more equality. More equal societies also have a higher likelihood of successful transitions as the "redistributive impact of democracy diminishes" (Boix, 2003: 3), and elites are more likely to allow universal suffrage. The V-Dem measures allow us to select cases that are comparable in terms of inequality before regime breakdown.

Sixth, there are important demographic factors to take into account. For instance, small countries are expected to have more input legitimacy, as they usually have more homogeneous societies (Dahl \& Tufte, 1973). We use data on population size from the Correlates of War project (Singer et al., 1972). Moreover, we know about the importance of the religious composition of a country for democracy (Lipset, 1994), especially the role of Islam, given that Muslim countries are "democratic underachievers" (Fish, 2002: 4). Our data set includes information on the Muslim population for all countries from the World Religion Project (Maoz \& Henderson, 2013). For similar reasons, we also look at ethnic fractionalization using data by Dražanová (2020). Some say that a lack of homogeneity in these terms reduces the prospects for democratization (Rabushka \& Shepsle, 1972).

Finally, we use information on regional levels of democracy as it affects the context in which the transition takes place. Democratic transitions should be easier to achieve when surrounded by already democratic states that can serve as role models and offer support for democratization. The variable also captures regional and potential global trends in democratization over time. The regional levels of democracy are calculated by averaging the level of V-Dem's Electoral Democracy Index in the geopolitical region defined by V-Dem's variable "e_regionpol" (Coppedge et al., 2020).

Table 1 presents all variables and data sources. Variables are measured one year before the year of regime breakdown (or the latest available year when data are missing). Given the high dimensionality of the dataset, we first reduced the number of dimensions using Principal Component Analysis (PCA). The PCA analysis reveals that over $90 \%$ of the variation in the data could be explained using the 11 first principal components (see Figure A.1 in the Appendix). 
Table 1. Structural variables included in the matching procedure

\begin{tabular}{|c|c|c|}
\hline & Variable & Source \\
\hline 1 & GDP per capita (log) & Penn World Tables V9.1 \\
\hline 2 & GDP growth per capita & Penn World Tables V9.1 \\
\hline 3 & Oil and gas production, per capita value & Ross and Mahdavi (2014) \\
\hline 4 & Infant mortality rate & Gapminder.org as provided by V-Dem (v10) \\
\hline 5 & Civil society strength & V-Dem (v10) v2xcs_ccsi index \\
\hline 6 & Human rights protection & Human Rights Protection Scores (v3.01) Fariss (2014) \\
\hline 7 & Party-based regime & Military dimension index \\
\hline 8 & Monarchy & Military dimension index \\
\hline 9 & Military regime & Military dimension index \\
\hline 10 & Military size per capita (log) & Correlates of War, NMC 5.0 \\
\hline 11 & Military expenditures per capita (log) & Correlates of War, NMC 5.0 \\
\hline 12 & Democracy & V-Dem (v10) v2x_polyarchy index \\
\hline 13 & Democratic experience & Cumulative sum of V-Dem's polyarchy index \\
\hline 14 & Leader tenure & REIGN data (Bell 2016) \\
\hline 15 & Coup attempt history & REIGN data (Bell 2016), sum of previous coup attempts \\
\hline 16 & Civil war (five-year average of conflict & UCDP/PRIO Armed Conflict Dataset (v19.1) \\
\hline 17 & Urban/rural divide & V-Dem (v10) v2pepwrgeo indicator \\
\hline 18 & Political group inequality & V-Dem (v10) v2clpolcl indicator \\
\hline 19 & Regional levels of democracy & V-Dem (v10) v2x_polyarchy index, average within e_regionpol \\
\hline 20 & Population (log) & Correlates of War, NMC 5.0 \\
\hline 21 & Percentage Muslim & World Religion Project (1.1) \\
\hline 22 & Ethnic fractionalization index & $\begin{array}{l}\text { Historical Index of Ethnic Fractionalisation Dataset } \\
\text { (Drazanova 2020) }\end{array}$ \\
\hline
\end{tabular}




\section{Measuring similarity between cases}

Based on the output from the principal component analysis, we calculated the pairwise Mahalanobis distances for all cases, using the caseMatch $\mathrm{R}$ package (Nielsen, 2016). Figure 1 summarizes the results. It presents a heatmap of all the pairwise distances between cases in the dataset. "Good" comparative cases, i.e., cases characterized by a short Mahalanobis distance, are colored in dark purple. "Bad" comparative cases, i.e., cases characterized by a large Mahalanobis distance, are represented by a lighter yellow color. In other words, the darkest square in each horizontal line marks the most similar transition in terms of structural background factors. The figure also shows that some transitions are similar to several other transitions while some appear to be rather "unique". For instance, Nepal's transition in 2006 (NPL-06) stands out as distinct due to the country's history of civil conflict, the power of the King and the county's lack of natural resources.

\section{Figure 1: Heat map of Pairwise Distances (Mahalanobis)}

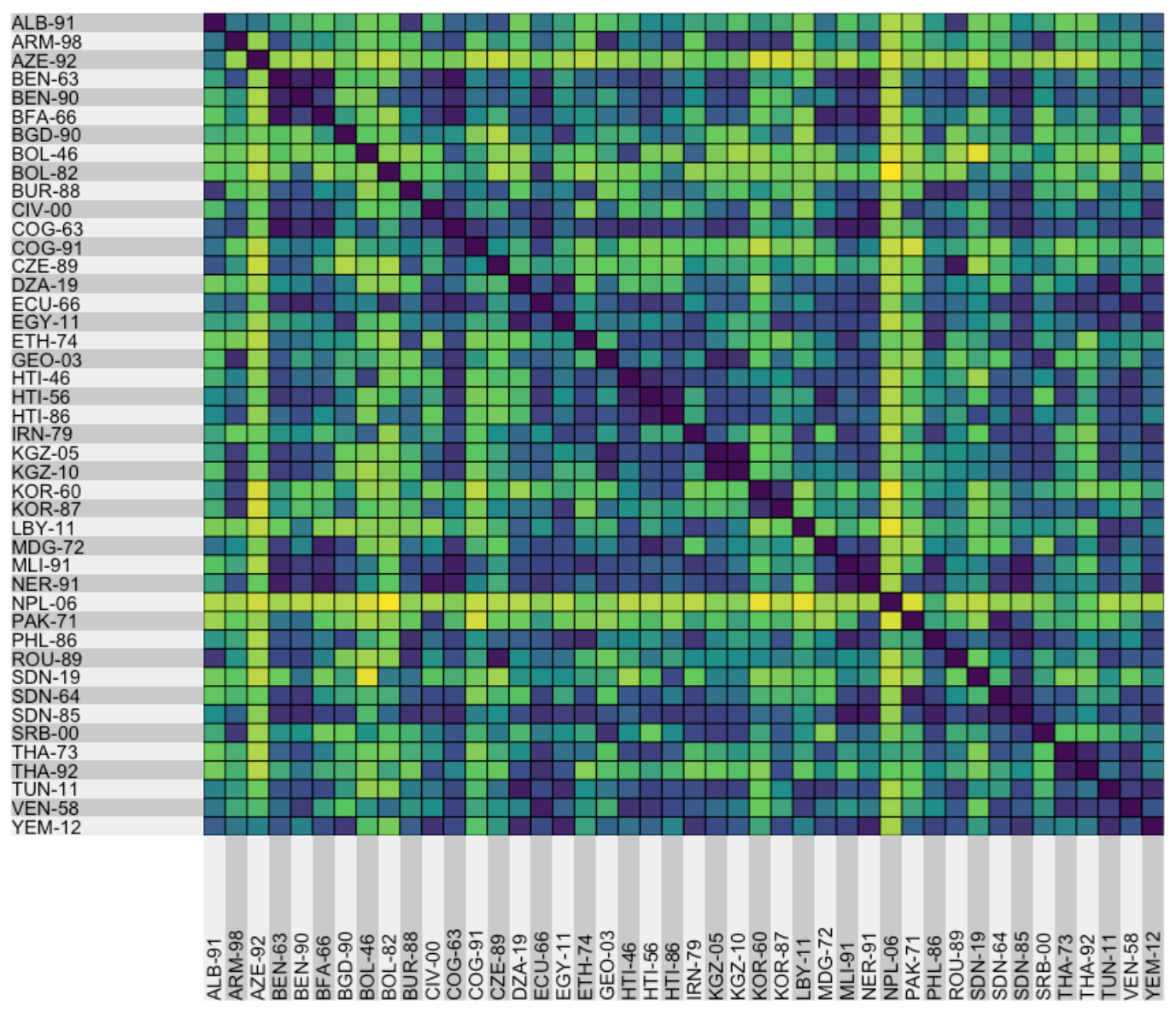

Note: The darker the color, the shorter the Mabalanobis distance and thus the more similar the cases. 


\section{Case study: Sudan in 2019}

Next, we focus on a specific case of authoritarian breakdown, Sudan in 2019, to demonstrate how the method can be used to learn lessons from the past. Figure 2 presents the evolution of democracy in Sudan based on V-Dem's Electoral Democracy Index (EDI, credible intervals shown in grey). Whereas Sudan has been authoritarian since its independence, it experienced two periods of partial liberalization. The first period began with the so-called "October Revolution" of 1964 that toppled president Ibrahim Abbud. The October Revolution ushered in a period of civilian rule and partial liberalization that ended with a military coup in 1969. The coup leader, Jaafar Nimeiri, himself lost power several years later in 1985 in a popular uprising, which marked the beginning of the second liberalization period. This second transition period did not lead to democracy either. It ended in 1989 with the coup of Omar al-Bashir (Hassan and Kadouda, 2019), who remained in power until 2019. In short, it is not the first time that a mass uprising leads to political liberation in Sudan. It is reasonable to study such past experiences in order to learn lessons on how to avoid a repetition of these historical scenarios (Dwamena, 2019).

\section{Figure 2: Democracy in Sudan (1955-2019)}

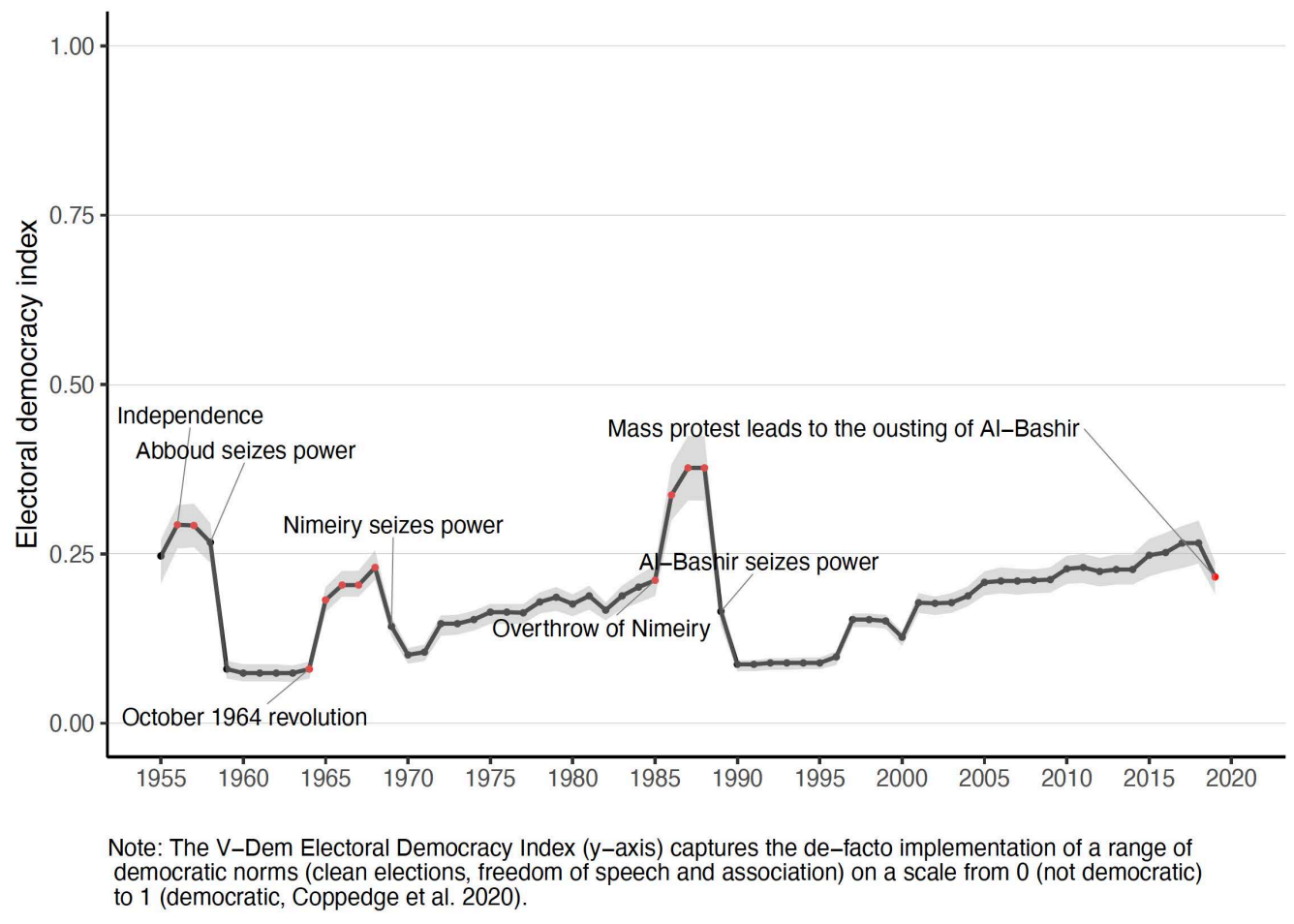

However, we propose that additional insights can be gained from looking at cases beyond Sudan. Whereas other cases of transition may appear very different at first sight, they resemble Sudan on a number of relevant dimensions. Figure 3 shows the pairwise distances between Sudan and all 
other cases of authoritarian breakdown in decreasing order of similarity. The five most similar cases to Sudan in 2019 are Sudan in 1985, Haiti in 1986, the Philippines in 1986, Benin in 1990, and Burma/Myanmar in 1988. These results are interesting for two reasons. First, they show that Sudan's transition in 2019 shares structural characteristics with several cases in addition to historical Sudan, suggesting that additional lessons can be learned from other countries beyond Northeastern Africa. Second, they show that Sudan in 2019 does not belong to a cluster of failed nor successful transitions. Among the cases of regime breakdowns caused by mass protests that are most similar to Sudan, we can find instances of both successful and failed democratization. These results are encouraging, as they suggest that although Sudan faces structural obstacles for democratization, it is not "destined to fail," given that other countries facing similar conditions have managed to democratize.

To ensure that our findings are not overly sensitive to the choice of variables included in the analysis, we assessed the robustness of our results to removing variables from the matching model. We reran the analysis using all combinations of 17 or more of these 22 variables $(26,334$ combinations in total). For each case of authoritarian breakdown, we calculated the proportion of analyses for which a given case was ranked among the five cases closest to Sudan in 2019. Figure 4 presents these proportions for all cases. It shows that Sudan in 1985, the Philippines in 1986, Benin in 1990, Burma/Myanmar in 1988 and Haiti in 1986 are ranked in the top five comparisons across most analyses - the same list of top five countries that also came out of the full model reported in Figure 3. These results increase confidence that the distances we computed are not overly sensitive to the choice of variables. 
Figure 3: Most similar cases to Sudan 2019 from a matching analysis

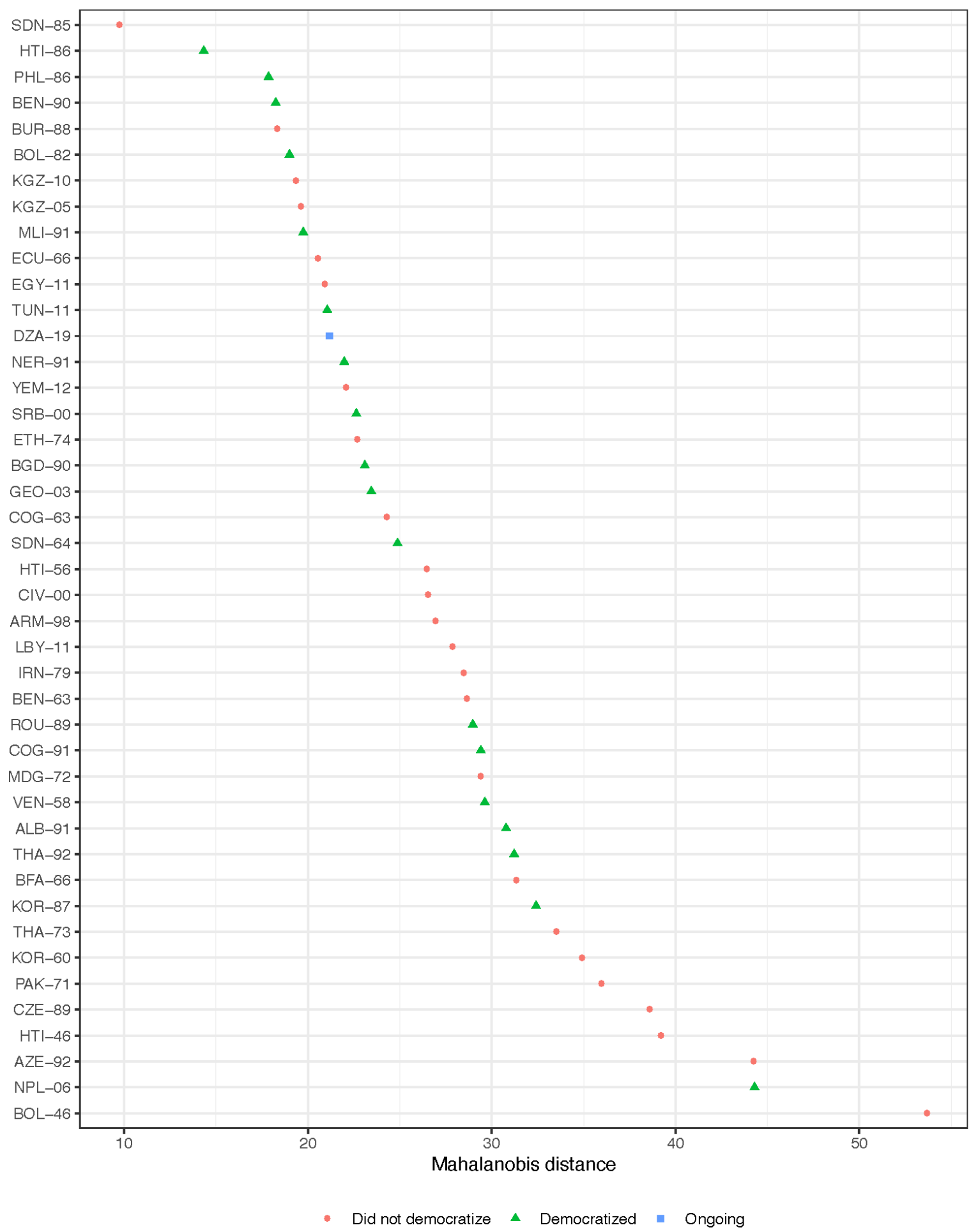


Figure 4: Sensitivity tests: Proportion of analyses with case ranked closest (top 5) to Sudan 2019 across 44,551 combinations of variables

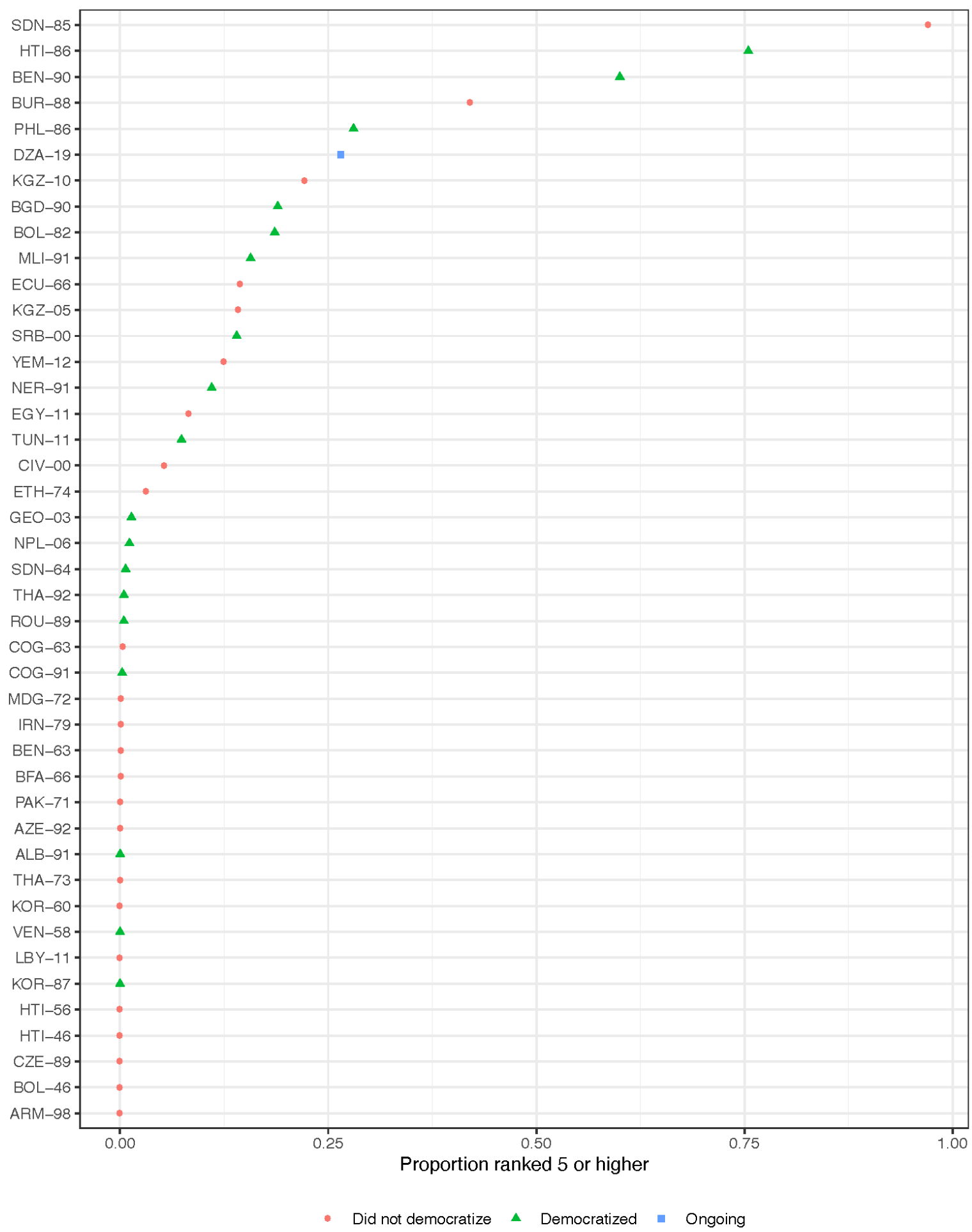


Our next and final step is a qualitative study of cases that are similar to Sudan in terms of structural factors to identify key choices and developments that had a significant impact on the outcome of the transition in these cases. Thereby, we can draw lessons for the ongoing transition in Sudan. For the analysis in the following section, we considered the five most similar cases as identified by the matching procedure. We decided not to look at Sudan's earlier transition as it is the obvious case to turn to for both activists in Sudan and analysts alike (see e.g., Dwamena, 2019). The strength of our approach is the identification of less obvious comparative cases. We also decided not to investigate the case of Haiti in 1986. Although Haiti is classified as a successful transition according to our definition (coded as democratic by GWF five years after the breakdown), there were important relapses to authoritarianism in the immediate post-transition period including two military coups. It is therefore a case of weak/unconsolidated democratization and not suitable for comparative analysis here.

Therefore, we selected two successful transitions, the Philippines in 1986 and Benin in 1990, as well as one failed transition, Burma/Myanmar in 1988, for our attempt to draw lessons for the situation in post-Bashir Sudan.

\section{The Philippines 1986 - successful democratization}

In 1986, large-scale protests against election fraud forced long-time dictator Ferdinand Marcos out of power, ushering in a successful transition to democracy in the Philippines. The new government, led by Corazon Aquino, faced several obstacles, including a highly politicized military and armed insurgencies by communist and Islamist groups. Factions loyal to Marcos tried to sabotage the transition on numerous occasions (Timberman, 1991: 169; Thompson, 2004: 28). Yet despite these obstacles, the Philippines succeeded in its transition to democracy. Figure 5 summarizes the development of democracy in the Philippines. 


\section{Figure 5: Democracy in the Philippines (1970-1990)}

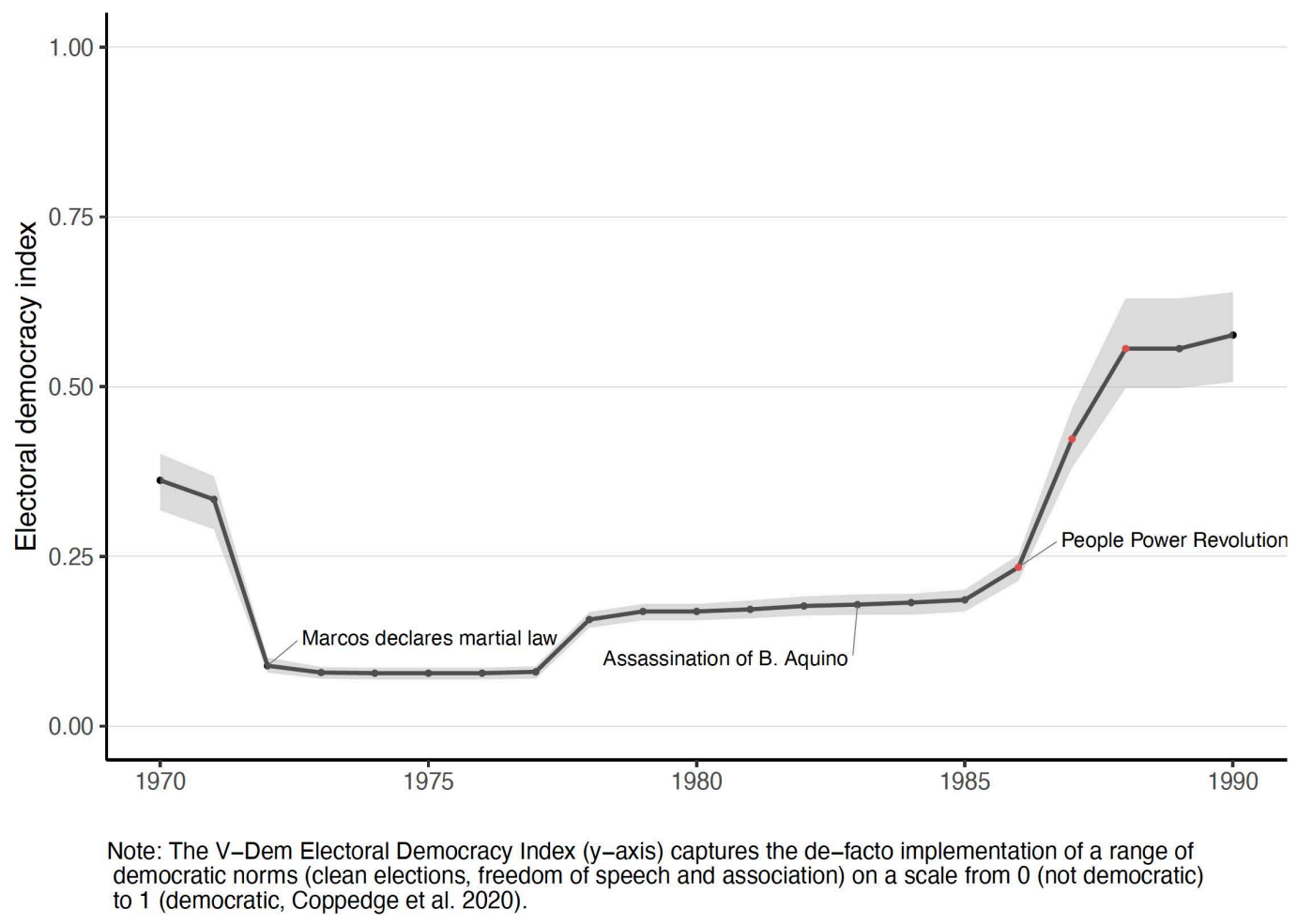

Existing literature on democratic transition in the Philippines points to several decisions that helped democracy take hold during the transition period. One often-noted element is the Aquino government's pragmatism and ability to maintain the support of so-called "constitutionalist" elements of the military who favored civilian rule. Shortly after gaining power, the new administration nearly lost officers' support when it sought reconciliation with communist insurgents, appointed left-leaning officials and demonstrated an interest in investigating human rights abuse and corruption within the armed forces (Timberman, 1991: 252). These decisions were highly unpopular amidst military ranks. Ultimately the government rescinded these decisions and secured these military factions' support by maintaining a hardline against insurgents, sacking the most controversial figures in the government and abandoning prosecution (Timberman, 1991: 225). Yet despite these efforts, the government faced insubordination among military ranks and suffered coup attempts by mutinous elements of the armed forces.

Second, the government adopted a cautious approach to reform and was able to maintain the support of a broad range of political forces including business interests and landlords (Thompson, 1996: 189). The approach of the presidency towards the controversial issue of agrarian reform was marked by caution in an effort to balance different societal interests. Sustained pressure from progressives and landholders led Aquino to decree a reform plan, which was characterized by a compromise between both camps and left much of the issue to be decided by congress (Putzel, 
1992: 235-236). Likewise, observers agree that the composition of the constitutional commission appointed by Aquino reflected broad interests (Abinales \& Amoroso, 2005: 233; Timberman, 1991: 178). Caution was also reflected in the government's restraint in using the powers at its disposal. For instance, the government refrained from declaring martial law after the coup attempt of August 1987 (Timberman 1991: 192, 200).

Third, pro-democratic forces were able to secure support from powerful international actors. Specifically, the United States played a crucial role in supporting the transition, condemning coup attempts against the transitional government and even intervening during the December 1989 putsch. This is despite the fact that the fall of Marcos, a long-time U.S. ally, and its replacement by a civilian government representing a broader range of political opinion, was plausibly threatening to U.S. interests. The military bases the U.S. maintained in the Philippines were unpopular and Aquino even pledged for their removal in the runoff to the presidential election in 1986. Yet she changed her position and successfully maintained U.S. support for the transition (Thompson, 1996: 190-191).

Even though the Philippine transition serves as a case of successful democratization (at least until a first decline in democratic quality at the beginning of the 2000s), there have also been some shortcomings that can inform cases like Sudan. This includes the failure of the civilian administration to institutionalize the people power movement. The Aquino government refrained from building a strong party organization that could have served as an independent power base. These deficiencies meant that the government had no other option than to rely on the support of moderate parts of the military and traditional political elites narrowing the leeway for political reform (Timberman 1991: 238-239).

\section{Benin 1990 - successful democratization}

In response to an ongoing economic crisis and growing domestic political unrest, the President of Benin, Mathieu Kérékou, convened a National Conference in 1990, which included both government and opposition forces. This conference paved the road for Benin's first free and fair elections in 1991.

According to Levitsky and Way (2010: 236), Benin in the early 1990s "lacked favourable conditions for democracy". Similar to many other authoritarian regimes in Africa, it was "poor, rural, and had small middle classes and weak civil societies" (ibid: 236). Thus, a successful democratization process in Benin did not seem very likely. Therefore, Benin is often referred to as a "deviant case" 
which is not well explained by structural theories of democratization (Gisselquist, 2008). And still, democratic transition in Benin was possible and did happen. Figure 6 illustrates the democratization process using V-Dem data.

In the case of Benin, most observers argue that the effective and inclusive way in which prodemocratic actors organized and pressured the transitional government was the key to democratic success. The activists first successfully pushed for their adequate inclusion in the National Conference in 1990 during the so-called "quota wars" (Bayer, 2018: 18). Gisselquist (2008: 807) further points out that it was critical that the actors involved in the National Conference did not focus on "narrow ethnic interests" but instead organized as "clearly 'Beninese' groups, representing the interests of students, businesses, trade unions, and so forth." Then they adopted political agendas and formed new parties to participate in the transitional elections in 1991 (Heilbrunn, 1993). After that, accountability mechanisms - elections, legislature, civil society, media and civil society - successfully constrained the power of subsequent presidents. For instance, a massive civil society campaign under the slogan of "Don't touch my constitution" stopped Kérékou, who ruled again from 1996-2006, and his successor Boni from extending term limits (Bayer, 2018: 30).

Figure 6: Democracy in Benin (1970-2000)

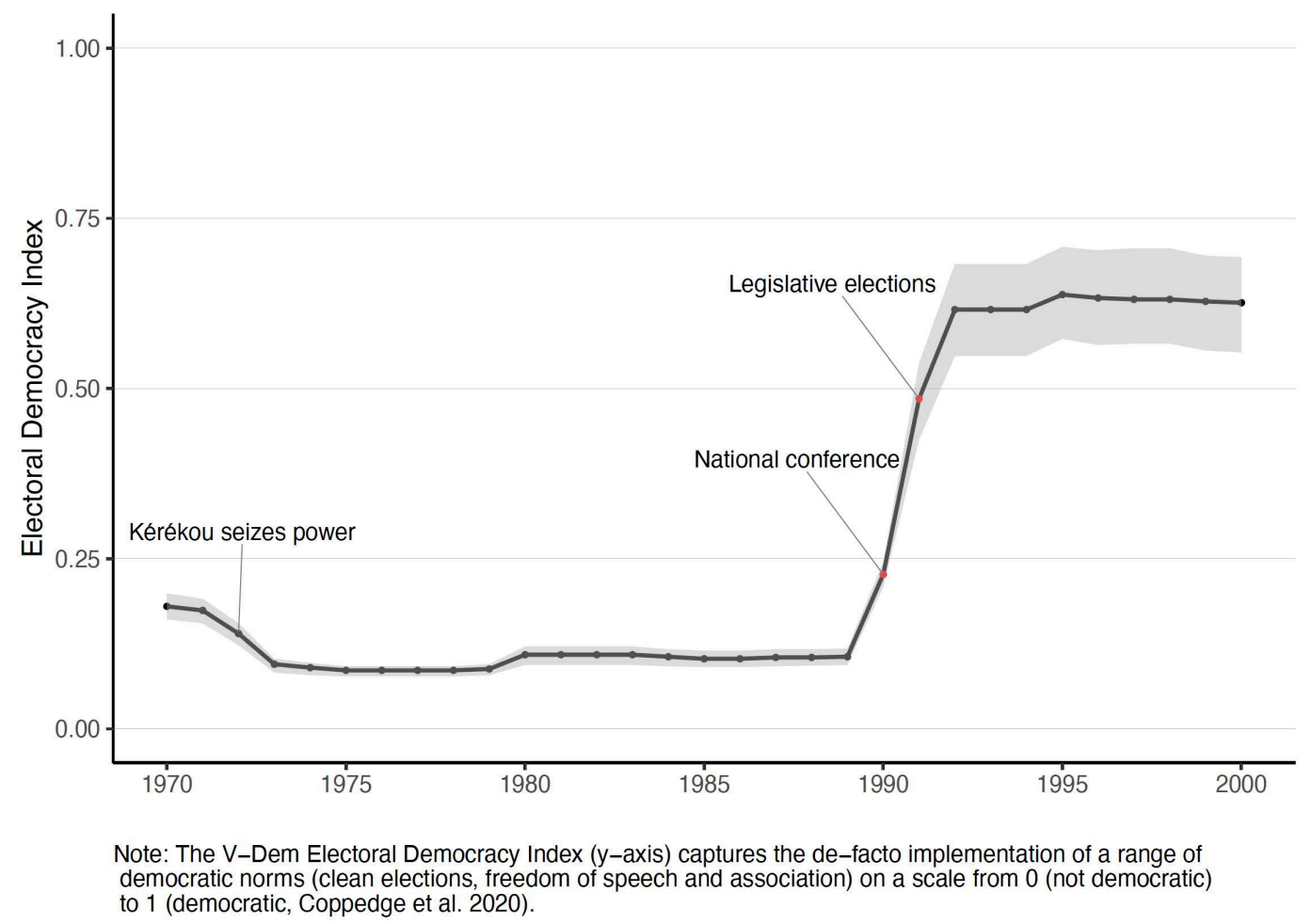

In the 1991 parliamentary election, 37 parties merged together in seven coalitions, competed and as in the National Congress some of them managed to bridge ethnic and regional divides 
(Heilbrunn, 1993: 295). Such cross-cutting cleavages and overlapping memberships of groups, are according to Cohen and Arato (1994), a "presupposition for a stable democratic polity, [and] a guarantee against permanent domination by any one group."

Still, diversity and ethnicity have shaped Benin's politics and the distribution of public goods, but none of the major candidates has tried gaining votes on this issue, thereby avoiding ethnic conflicts (Gisselquist, 2008). Levitsky and Way (2010: 294) further suggest that party and state weakness helped democracy in Benin. No political leader controlled a party that was strong enough to muster support for abusing power or weakening the opposition.

Three additional factors for Benin's success are often emphasized in the literature: reconciliation, the weak military and international assistance. First, many observers note that swift reconciliation with old regime elites was highly conducive to the success of democratization (Bayer, 2018: 18; Gisselquist, 2008; Heilbrunn, 1993; Nzouankeu, 1993). After the transitional elections, incumbent Kérékou only conceded electoral defeat "when he was granted immunity for crimes committed during his term in office" (Gisselquist, 2008: 798). This allowed him to leave "in honor" (Bayer, 2018: 18). However, the Beninese Communist Party, the strongest pro-democracy party at the time, was opposed to the reconciliatory approach and even boycotted the National Conference demanding that Kérékou be prosecuted (Gisselquist, 2008: 796). Thus, the decision not to trial members of the authoritarian regime elite could have jeopardized the transitional process.

Second, Benin's military was small and it did not attempt to spoil the transition. For instance, Kérékou's Presidential Guard numbered no more than two thousand (Decalo, 1997: 47). Furthermore, military officers did not remain loyal to Kérékou. Whereas hardliners within the regime pressed Kérékou to dissolve the Conference, the military clearly signaled they would not back such a move (Decalo, 1997: 51-53; Omitoogun \& Onigo-Itite, 1996: 16).

Third, international actors - in particular the French government - clearly backed the democratic transition by offering to pay for the National Congress (Gisselquist, 2008: 796, 807) and providing economic assistance to the first democratically elected government (Bayer, 2018: 18).

As Figure 6 indicates, Benin achieved stable levels of democracy following the transition at the beginning of the 1990s and despite some very recent drawbacks, Freedom House stated in 2019 that Benin "remains among the most stable democracies in sub-Saharan Africa, having witnessed 
multiple free and fair elections and peaceful transfers of power since its transition to democracy in $1991 \% .4$

\section{Burma/Myanmar 1988 - failed democratization}

The wave of protests that led to the 1988 popular uprising in Burma/Myanmar began in September 1987 when president Ne Win "eliminated 25-, 35-, and 75-Kyat currency notes, nullifying between 60 and 80 percent of the currency in circulation" (Thompson, 1999: 34), sparking broad uproar and a wave of student protests. Protestors achieved a partial victory when Ne Win resigned on 23 July in 1988. However, he appointed General Sein Lwin - notorious for atrocities - as his successor, thus sparking more protests. On 8 August 1988 the unrest culminated in a nationwide general strike (the "8-8-88 uprising") and hundreds of thousands protesting across the country. Figure 7 gives an overview of the timeline of the (failed) transition.

\section{Figure 7: Democracy in Burma/Myanmar (1960-2000)}

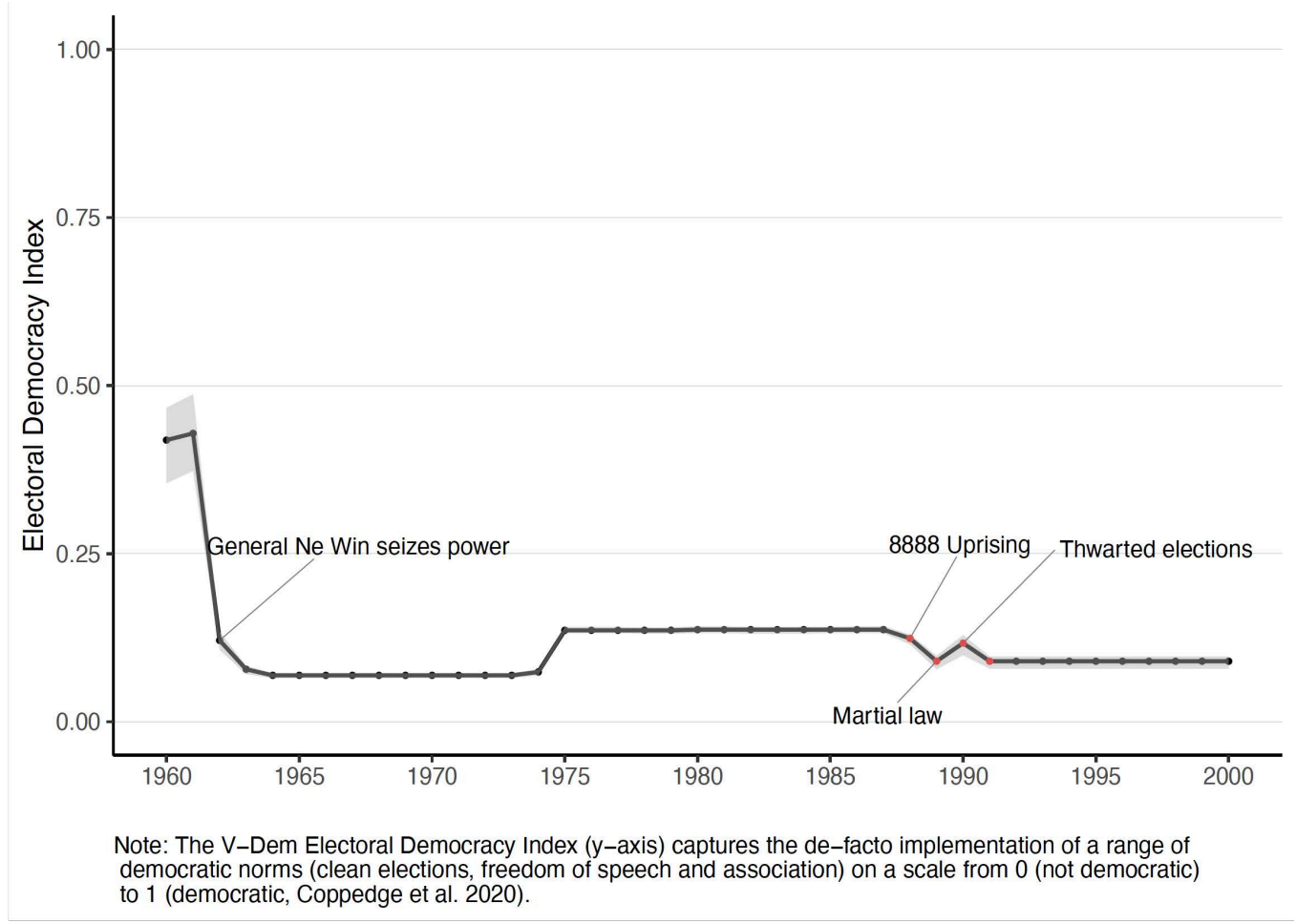

On 12 August 1988 Sein Lwin resigned suddenly and without explanation, which "left many protestors confused and jubilant" (Boudreau, 2004: 205). Following pressure to form a civilian government, writer Dr. Maung Maung was appointed as head of government on 19 August and both protests and repression halted briefly (Fink, 2001). During this "democracy summer", many former democracy leaders returned, such as former Prime Minister U Nu, retired Brigadier General

\footnotetext{
${ }^{4}$ See https:/ / freedomhouse.org/country/benin/freedom-world/2019
} 
Aung Gyi (Smith, 1999), and Aung San Suu Kyi, 1991 Nobel Peace Prize laureate, entered the political arena and joined with the protestors, urging the crowd not to turn on the army but find peace through nonviolent means (Fink, 2001: 60; Fong, 2008: 150).

The ruling Burma Socialist Programme Party (BSPP) announced they would be organizing an election, but opposition parties called for the party's immediate resignation, the creation of an interim government and quick elections (Fong, 2008: 150) After the BSPP rejected these demands, protesters again took to the streets on 12 September 1988 (Fong, 2008: 150), demanding immediate change (Maung, 1999).

The peaceful protests were met with violent repression by the military, which gained control of the country in September 1988 (Alagappa, 1995: 170; Smith, 1999). General Saw Maung abolished the 1974 constitution and installed the State Law and Order Restoration Council (SLORC). He became an even more repressive leader than former Prime Minister Ne Win (Delang, 2000). Thousands of protesters were killed or disappeared and the movement collapsed in October 1988 (Tucker 2011: 291).

Nevertheless, in May 1990, the SLORC held (relatively) free elections, which the opposition party, the National League for Democracy (NLD) won unexpectedly, whereas the National Unity Party (NUP), favored by the military, clearly lost. However, the SLORC refused to convene a Legislative Assembly after the elections and to hand over power. Instead, it ruled until 2011 without meaningful democratization (see Figure 7).

Why did democratization fail in Burma/Myanmar? And could pro-democratic activists have done anything differently to achieve a better outcome? The clearest political opening was from August to September 1988. In August 1988, Dr. Maung Maung, a civilian, was appointed chairman of the BSPP and head of government (Fink, 2001). He offered to organize multiparty elections within three months (Tonkin, 2007: 37). Yet this offer was rejected by the opposition and its emerging political leaders, Daw Aung San Suu Kyi, Aung Gyi, Tin Oo and U Nu. These opposition leaders did not recognize the Election Commission as impartial because it had been appointed by a compromised administration (Tonkin, 2007: 37). Instead, they called for the government's immediate resignation and the establishment of an interim administration composed of non-BSPP personalities to allow an interim government to organize elections (Fong, 2008: 150; Tonkin, 2007: 37). The BSPP rejected those demands and protesters took to the streets again on 12 September 1988 (Fong, 2008: 150). 
Tonkin (2007: 37) argues that it "is possible that if the emerging political leaders [...] had agreed to this [the BSPP's proposal] and had been willing to accept the nominated Election Commission to supervise the elections, the 18 September 1988 coup might never have happened". That said, protesters in Burma/Myanmar had reasons to worry about the BSPP's proposal. According to Reilly (2016: 13), "establishing an independent electoral commission should be one of the first steps in a transitional electoral timetable". The election management in Burma/Myanmar was not independent at that time. Even though being one of the key demands of the opposition, the government never granted them representation in the election commission (Watcher, 1989: 180). Thus, it is not obvious that Burma would have democratized had the protesters agreed to elections without institutional safeguards.

Furthermore, after the 18 September coup, many students did not regroup as peaceful protesters; instead, they chose armed struggle against the SLORC and fled to the jungle (Thompson, 1999: 36). They put their hopes in receiving support from foreign countries and cooperating with ethnic insurgents - hopes which never were fulfilled (Thompson, 1999: 36). Instead, the military intensified its grip on political power.

\section{Discussion}

In order for a democratic transition to succeed, several factors need to align. In Benin in 1990, pro-democratic forces were relatively united in their desire to make democracy work. They maintained a commitment to pluralism and no societal group reneged on democracy out of fear that a rival group would dominate. Furthermore, the military decided not to intervene on the side of the former dictator, Kérékou, who conceded defeat in the transitional elections thanks to an amnesty guarantee. In the Philippines in 1986, the Aquino government dealt with dissatisfaction within the military and even suffered coup attempts that almost ended the democratic transition. Yet it was able to maintain the support of core factions within the military through a politics of moderation and compromise. Likewise, the Aquino government was able to obtain support from the United States for the democratic transition. The support of a powerful foreign patron in favor of democracy likely played an important role in preventing its democratic breakdown. In Burma/Myanmar in 1988, it is difficult to attribute democratization failure to one specific factor or decision made by pro-democratic forces. The military decided to crack down on the protests instead of becoming a partner in the democratic transition process. 


\section{Conclusions}

This study proposes an innovative, quantitative strategy for identifying cases for comparative studies on successful and failing transitional processes. Comparing all 44 successful and failed transitions to democracy since 1945 based on 22 key structural factors and matching techniques allows us to identify suitable, similar cases for comparison beyond the typical, regional approach.

In an empirical application of this method, we draw lessons that can be helpful for understanding the current transition in Sudan. Almost two years after the overthrow of long-time dictator Omar $\mathrm{Al}-\mathrm{Bashir}$, the transition is still ongoing and its outcome is uncertain. Our paper reports some reason for cautious optimism for Sudan. Out of the four historical cases that are most similar to Sudan in 2019, two democratized --- Benin 1990 and the Philippines in 1986 --- and two did not, Myanmar in 1988 and Sudan in 1986. This analysis suggests that despite the major challenges faced, the outcome of the transition in Sudan is not pre-determined by structural conditions.

Whereas structural factors do not determine the fate of these transitions, they still can create substantial challenges for pro-democratic actors and may strengthen the position of nondemocratic actors, including security forces. An entrenched military that believes a democratic transition threatens its interest, or a foreign power that is unwilling to support the democratic process, can be enough to derail democratization efforts.

What can pro-democracy activists in Sudan learn from failed and successful democratization efforts in the Philippines, Benin and Myanmar? The case studies have shown the importance of maintaining broad alliances and the willingness to compromise on specific policy issues and reforms. At the same time - while it is important that activists and the military cooperate, activists should push back against military overreach during the transition. Pro-democracy forces need to make sure that civilian actors are represented in transitional governance bodies and are able to keep the military in check. Mass-based nonviolent action can help to ensure accountability of elites and steer the transition process. Finally, international support can be conducive to democratization.

Despite the fact that the Sudanese transition process has already come further than Burma/Myanmar in 1988, the country has a history of short-lived time periods where it seemed that civilian rule was possible (1956-57; 1964-69; 1985-1989). While the process in Sudan is fragile, the Juba peace agreement and the Sudan partnership conference with the European Union and the United Nations in 2020 are rays of hope. To not repeat the mistakes of the past, pro-democratic 
actors may turn to successful cases of democratic transition in similar structural contexts for inspiration. 


\section{References}

Abinales, Patricio N and Donna J Amoroso (2005) State and Society in the Philippines. London: Rowman \& Littlefield.

Alagappa, Muthiah (1995) Political legitimacy in Southeast Asia: The quest for moral authority. Stanford University Press.

Anckar, Carsten (2008) On the applicability of the most similar systems design and the most different systems design in comparative research. International Journal of Social Research Methodology, 11(5), 389401.

Bayer, Markus (2018) The Democratizing Effect of Non-violent Resistance: How Nonviolent Resistance Featured Democratic Consolidation in Benin: Swisspeace.

Belkin, Aaron and Evan Schofer (2003) Toward a structural understanding of coup risk. Journal of Conflict Resolution, 47(5), 594--620.

Bell, Curtis (2016) The Rulers, Elections, and Irregular Governance Dataset (REIGN): OEF Research.

Bernhard, Michael and Ekrem Karakoc (2007) Civil society and the legacies of dictatorship. World Politics, 59(4), 539--567.

Bogaards, Matthijs (2019) Case-based research on democratization. Democratization, 26(1), 61-77.

Boix, Carles (2003) Democracy and redistribution: Cambridge University Press.

Boudreau, Vincent (2004) Resisting dictatorship: Repression and protest in Southeast Asia: Cambridge University Press.

Brady, Henry E, and David Collier (2004) Rethinking Social Inquiry: Diverse Tools, Shared Standards. Lanham, Md.: Rowman and Littlefield.

Brancati, Dawn and Jack L Snyder (2013) Time to Kill: The Impact of Election Timing on Postconflict Stability. Journal of Conflict Resolution, 57(5), 822-853.

Bratton, Michael and Nicholas van de Walle (1997) Democratic experiments in Africa: Regime transitions in comparative perspective: Cambridge University Press.

Brownlee, Jason, Tarek Masoud and Andrew Reynolds (2015) The Arab Spring: Pathways of repression and reform. New York: Oxford University Press, USA.

Dwamena, Anakwa. "The Historical Precedents of the Current Uprising in Sudan," The New Yorker, February 8, 2019.

Croissant, Aurel, David Kuehn and Tanja Eschenauer (2018) The "dictator's endgame": Explaining military behavior in nonviolent anti-incumbent mass protests. Democracy and Security, 14(2), 174-199.

Coppedge, Michael, John Gerring, Carl Henrik Knutsen, Staffan I. Lindberg, Jan Teorell, David Altman, Michael Bernhard, M. Steven Fish, Adam Glynn, Allen Hicken, Anna Luhrmann, Kyle L. Marquardt, Kelly McMann, Pamela Paxton, Daniel Pemstein, Brigitte Seim, Rachel Sigman, Svend-Erik Skaaning, Jeffrey Staton, Steven Wilson, Agnes Cornell, Nazifa Alizada, Lisa Gastaldi, Haakon Gjerløw, Garry Hindle, Nina Ilchenko, Laura Maxwell, Valeriya Mechkova, Juraj Medzihorsky, Johannes von Römer, Aksel Sundström, Eitan Tzelgov, Yi-ting Wang, Tore Wig, and Daniel Ziblatt. 2020. "V-Dem [Country-Year/Country-Date] Dataset v10". Varieties of Democracy (V-Dem) Project. https://doi.org/10.23696/vdemds20.

Coppedge, Michael, John Gerring, Carl Henrik Knutsen, Staffan I. Lindberg, Jan Teorell, David Altman, Michael Bernhard, M. Steven Fish, Adam Glynn, Allen Hicken, Anna Luhrmann, Kyle L. Marquardt, 
Kelly McMann, Pamela Paxton, Daniel Pemstein, Brigitte Seim, Rachel Sigman, Svend-Erik Skaaning, Jeffrey Staton, Agnes Cornell, Lisa Gastaldi, Haakon Gjerløw, Valeriya Mechkova, Johannes von Römer, Aksel Sundtröm, Eitan Tzelgov, Luca Uberti, Yi-ting Wang, Tore Wig, and Daniel Ziblatt. 2020. "V-Dem Codebook v10". V arieties of Democracy (V-Dem) Project.

Dahl, Robert Alan and Edward R Tufte, (1973) Siže and democracy (Vol. 2): Stanford University Press.

Decalo, Samuel (1997) Benin: First of the new democracies. In John F Clark and David E Gardinier (Eds.), Political Reform in Francophone Africa (pp. 43-61): Routledge.

Delang, Claudio (2000) Suffering in silence: The buman rights nightmare of the Karen people of Burma. Parkland, USA: Universal Publishers.

De Meur, Gisèle and Dirk Berg-Schlosser (1996) Conditions of Authoritarianism, Fascism, And Democracy in Interwar Europe. Comparative Political Studies, 29(4), 423-468.

Di Palma, Giuseppe (1990) To Craft Democracies. An Essay on Democratic Transitions. Berkeley: University of California Press.

Dražanová, Lenka (2020) Introducing the Historical Index of Ethnic Fractionalization (HIEF) Dataset: Accounting for Longitudinal Changes in Ethnic Diversity. Journal of Open Humanities Data, 6(1), 6.

Fariss, Christopher J (2014) Respect for human rights has improved over time: Modeling the changing standard of accountability. American Political Science Review, 108(2), 297-318.

Feenstra, Robert C, Robert Inklaar, and Marcel P Timmer, (2015) The next generation of the Penn World Table. American Economic Review, 105(10), 3150--3182.

Fink, Christina (2001). Living silence: Burma under military rule. Zed Books.

Fish, M Steven (2002) Islam and authoritarianism. World Politics, 55(1), 4--37.

Fong, Jack (2008). Revolution as Development: The Karen Self-Determination Struggle Against Ethnocracy (1949-2004). Brown Walker Press.

Geddes, Barbara (2013) What causes democratization? In: Goodin, Robert E (ed.). The Oxford Handbook of Political Science. Oxford: Oxford University Press.

Geddes, Barbara, Joseph Wright and Erica Frantz (2014) Autocratic breakdown and regime transitions: A new data set. Perspectives on Politics, 12(02), 313--331.

Gisselquist, Rachel M (2008) Democratic Transition and Democratic Survival in Benin. Democratization, 15(4), 789-814.

Hale, Henry E (2008) Why not parties in Russia. Cambridge University Press.

Haggard, Stephan and Robert R Kaufman (2018) The political economy of democratic transitions. Princeton University Press.

Hassan, Mai and Ahmed Kodouda (2019) Sudan's Uprising: The Fall of a Dictator. Journal of Democracy, (4), 89-103.

Heilbrunn, John R (1993) Social Origins of National Conferences in Benin and Togo. The Journal of Modern African Studies, 31(2), 277-299.

Ho, Daniel E, Kosuke Imai, Gary King, and Elizabeth A Stuart (2007) Matching as Nonparametric Preprocessing for Reducing Model Dependence in Parametric Causal Inference. Political Analysis, 15, 199-236. 
Iacus, Stefano M, Gary King and Guiseppe Porro (2012) Causal Inference Without Balance Checking: Coarsened Exact Matching. Political Analysis, 20(1), 1-24.

Imai, Kosuke and Marc Ratkovic, (2014) Covariate balancing propensity score. J. R. Stat. Soc. B, 76, 243263.

Inglehart, Ronald and Christian Welzel (2009) How development leads to democracy: What we know about modernization. Foreign Affairs, 33-48.

Ketchley, Neil (2017) Egypt in a Time of Revolution Contentious Politics and the Arab Spring. New York, NY: Cambridge University Press.

King, Gary, Robert O Keohane, and Sidney Verba (1994) Designing Social Inquiry. Scientific Inference in Qualitative Research. Princeton University Press.

Levitsky, Steven, and Lucan A Way (2010) Competitive authoritarianism: Hybrid regimes after the Cold War. Cambridge University Press.

Lijphart, Arend (1971) Comparative Politics and the Comparative Method. American Journal of Political Science, 65(3), 682-693.

Lipset, Seymour Martin (1994) The social requisites of democracy revisited: 1993 Presidential Address. American Journal of Sociology, 59(1), 1--22.

Lührmann, Anna, Marcus Tannenberg and Staffan I Lindberg (2018) Regimes of the world (RoW): Opening new avenues for the comparative study of political regimes. Politics and Governance, 6(1), 6077.

Maoz, Zeev and Errol A Henderson (2013) The world religion dataset, 1945--2010: Logic, estimates, and trends. International Interactions, 39(3), 265--291.

Maung, Maung (1999) The 1988 uprising in Burma: Yale University Southeast Asia Studies.

Morency-Laflamme, Julien (2018) A question of trust: military defection during regime crises in Benin and Togo. Democratization, 25(3), 464-480.

Nielsen, Richard A (2016) Case Selection via Matching. Sociological Methods \& Research, 45(3), 569-597.

Nzouankeu, Jacques Mariel (1993) The Role of the National Conference in the Transition to Democracy in Africa: the cases of Benin and Mali. African Issues, 21(1-2), 44-50.

Omitoogun, Wuyi (1996) The National Conference as a Model for Democratic Consolidation: Benin and Nigeria. Dans Africa Occasional Paper. Ibadan, Nigeria: French Institute for Research (IFRA).

Pemstein, Daniel, Kyle L. Marquardt, Eitan Tzelgov, Yi-ting Wang, Juraj Medzihorsky, Joshua Krusell, Farhad Miri, and Johannes von Römer. 2020. "The V-Dem Measurement Model: Latent Variable Analysis for Cross-National and Cross-Temporal Expert-Coded Data”. V-Dem Working Paper No. 21. 5th edition. University of Gothenburg: Varieties of Democracy Institute.

Pinckney, Jonathan (2020) From dissent to democracy. The promise and perils of civil resistance transitions. New York: Oxford University Press.

Przeworski, Adam (1995) Sustainable Democracy. Cambridge: Cambridge University Press.

Putzel, James (1992) A Captive Land: The Politics of Agrarian Reform in the Pbilippines. Manila: Ateneo de Manila University Press.

Quinn, Joanna R (2009) Reconciliation(s): Transitional Justice in Postconflict Societies. Montreal, Canada: McGillQueen's University Press. 
Rabushka, Alvin and Kenneth A Shepsle (1972) Politics in plural societies. Columbus, OH: Charles E. Merrill, 232.

Reilly, Benjamin (2016) Timing and sequencing in post-conflict elections. Oxford: Oxford University Press.

Ross, Micheal L (2001) Does oil hinder democracy? World Politics, 53(3), 325--361.

Ross, Michael and Paasha Mahdavi (2015) Oil and Gas Data, 1932-2014.

Singer, David J, Stuart Bremer and John Stuckey (1972) Capability Distribution, Uncertainty, and Major Power War, 1820-1965. In. Peace, War, and Numbers: Sage.

Smith, Martin (1999) Burma: Insurgency and the Politics of Ethnicity. Dhaka: University of Michigan Press.

Sundberg, Ralph and Erik Melander (2013) Introducing the UCDP Georeferenced Event Dataset. Journal of Peace Research, 50(4), 523--532.

Thompson, Nick (1999) What makes a revolution? Burma's revolt of 1988 and a comparative analysis of the revolutions of the late 1980s. Studies in Conflict and Terrorism, 22(1), 33-52.

Thompson, Mark R (1996) Off the Endangered List: Philippine Democratization in Comparative Perspective. Comparative Politics, 28(2), 179-205.

Thompson, Mark R (2004) Democratic revolutions: Asia and Eastern Europe (1st ed.). Routledge research in comparative politics: Vol. 5. Routledge.

Timberman, David G (1991) A changeless land: Continuity and change in Philippine politics. Sharpe.

Tonkin, Derek (2007) The 1990 elections in Myanmar: broken promises or a failure of communication? Contemporary Southeast Asia, 33-54.

Tucker, Shelby (2001) Burma: Curse of independence: Pluto Press.

Watcher, Burma (1989) Burma in 1988: There came a whirlwind. Asian Survey, 29(2), 174-180.

White, Gordon (1994) Civil society, democratization and development (I): Clearing the analytical ground. Democratization, 1(2), 375--390. 


\section{Appendix}

Figure A.1: Variance explained by principal components

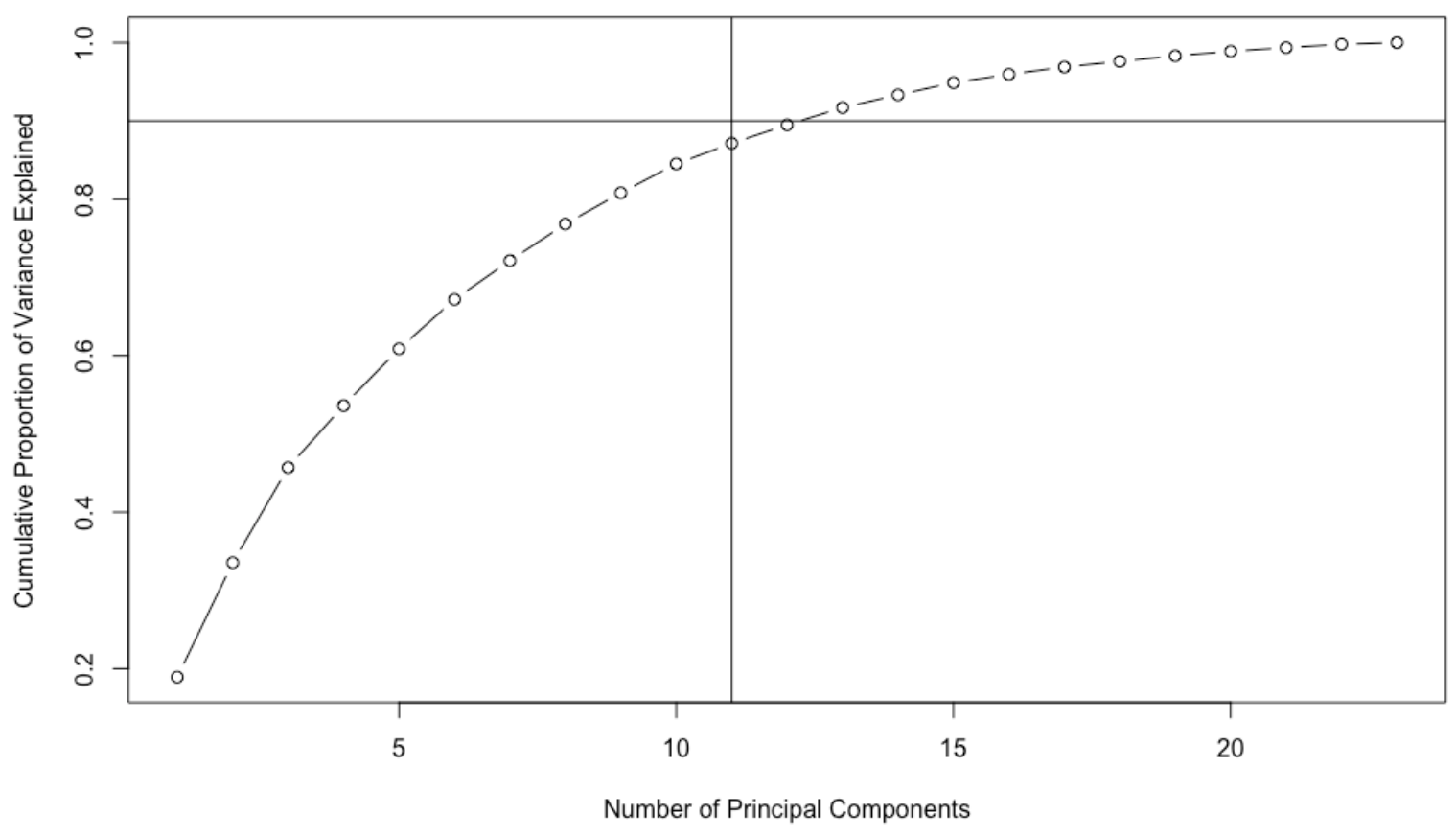

